\title{
MEASURING OPERATIONAL AFFORDABILITY OF PUBLIC LOW-COST HOUSING IN KUALA LUMPUR. CASE STUDY OF PEOPLE'S HOUSING PROGRAMME PUBLIC LOW-COST HOUSING IN KUALA LUMPUR
}

\section{SUZAINI MOHAMED ZAID}

\begin{abstract}
:
Affordability in housing is often defined by the ratio of purchase price or rent, to total household income. At present, public low-cost housing units in Malaysia are sold or rented at below market price value being subsidized by the government. This housing affordability definition overlooks other important issues such as long-term operational costs, where a typical low-income household spends a substantial share of monthly income on energy and utility services such as electricity and water. Consequently, the apportionment or percentage of average household income spent on operational household expenditure such as rent, electricity and other utilities are investigated in this paper, by using a survey questionnaire and interview techniques. This paper presents a brief overview to how low-cost housing can contribute to sustainable development in terms of long-term operational affordability for social and economical sustainability.
\end{abstract}

\section{Keywords:}

Public housing; Low-cost housing; Sustainable urban housing; Triple-bottom-line; Housing Policy

JEL Classification: 018

\section{Authors:}

SUZAINI MOHAMED ZAID, University of Malaya, Faculty of Built Environment, Malaysia, Email: suzaini_zaid@um.edu.my

\section{Citation:}

SUZAINI MOHAMED ZAID (2015). Measuring Operational Affordability of Public Low-Cost Housing in Kuala Lumpur. Case study of People's Housing Programme Public Low-Cost Housing in Kuala Lumpur. International Journal of Social Sciences, Vol. IV(4), pp. 54-74., 10.20472/SS.2015.4.4.005 


\section{Introduction}

Rapid urbanization and the scale of new buildings constructed in Malaysia demonstrate an urgent need for change in policy and mode of operation. The government's response to the increasing housing demand in urban areas for the lower-income population is manifested through low-cost housing projects, in subsidized sale price and/or low monthly rental. This current definition of low-cost housing excludes other operational costs such as energy and water utilities, therefore long-term affordability remains uncertain. Consequently, operational affordability of public low-cost housing, in terms of apportionment/percentage of average household income spent on operational household expenditure such as rent, electricity and other utilities is reported in this paper.

Low-cost housing in Malaysia is provided by both private (through private developers and cooperative societies) and public sectors (through housing land schemes and governmental agencies) (EPU, 2006). Private housing developers in Malaysia are obliged to provide at least $30 \%$ of new residential development for low-cost units, unless expressly permitted otherwise (Aziz, 2007; EPU, 2006; REHDA, 2008). Public low-cost housing is provided by different agencies and authorities from Federal, State and local levels, such as the Ministry of Rural and Regional Development, National Housing Department (NHD), City and Hall of Kuala Lumpur (CHKL) (EPU, 2010; National Housing Department, 2011).

According to the Tenth Malaysia Plan (2011-2015), a total of 95,800 low-cost housing units were built during the Ninth Malaysia Plan (2006-2010) (EPU, 2010). Approximately 42,300 units of low-cost housing (44.2\%) were built by the public sector ${ }^{1}$ and 53,500 units (55.8\%) built by the private sector (EPU, 2010). However, based on a nation-wide States government census, as of $30^{\text {th }}$ June 2010 , there were 90,282 squatter households that had not been relocated (National Housing Department, 2011). This exemplifies insufficient provisions by both the public and private sector to meet the growing demand for low-cost housing, and the importance of low-cost housing within the residential context. This growing demand is due to a growing urban population, where the housing market is extensive and purchasing power is higher than rural areas (National Housing Department, 2011). 


\section{$2 \quad$ Housing Typology in Kuala Lumpur}

The housing industry is mainly categorized as private and public housing sectors, and further subdivided into other housing programmes. The public sector's housing programmes include low-cost housing; housing for the hardcore poor (PPRT); sites and services; housing by commercial agencies; housing by land schemes; and institutional quarters and staff accommodation. The private sector housing programmes are subdivided to private developers and cooperative societies (EPU, 2006). The housing typology is then subcategorized into five (5) category namely; housing for the poor; low-cost; low-medium cost; medium cost; and high-cost housing (EPU, 2006). Based on this subcategory and housing programmes, both the public and private sectors are responsible for allocating lowcost housing provision. However the "housing for the poor" subcategory, falls under the direct responsibility of the public sector; under the PPRT and sites and services housing programmes (EPU, 2006).

In urban areas, the housing typology ranges between low-cost and high-cost housing, are further categorized into landed or subdivided properties (MM2H, 2009). Most of the rural area housing in Malaysia can be categorized as vernacular architecture, which design varies between the assorted states. The rural area housing shall not be explored because the distinct aim of this research is to investigate the urban housing conditions. According to the National Property Information Centre (NAPIC), there are a total of 440,696 housing units available in Kuala Lumpur (NAPIC, 2015) (refer Table 1). The largest percentage of housing typology available in Kuala Lumpur is the Condominium or Apartment typology, with a percentage of approximately $36 \%$, while the second highest housing typology percentage is the Low-Cost Flat at approximately $22 \%$. The lowest housing typology available in Kuala Lumpur is the Single Storey Semi-Detached at only $0.1 \%$ and Low-Cost House at approximately $0.9 \%$ of the total existing housing typology in Kuala Lumpur.

Table 1 Residential Stock in Kuala Lumpur Q1 2015 Source: NAPIC (2015)

\begin{tabular}{|c|c|c|c|c|c|c|c|c|c|c|c|}
\hline $\begin{array}{l}\text { Singl } \\
\text { e } \\
\text { Store } \\
\text { y } \\
\text { Terra } \\
\text { ce }\end{array}$ & $\begin{array}{l}2-3 \\
\text { Store } \\
\text { y } \\
\text { Terra } \\
\text { ce }\end{array}$ & $\begin{array}{l}\text { Singl } \\
\text { e } \\
\text { Store } \\
\text { y } \\
\text { Semi } \\
-D\end{array}$ & $\begin{array}{l}2-3 \\
\text { Store } \\
y \\
\text { Semi } \\
-D\end{array}$ & $\begin{array}{l}\text { Deta } \\
\text { ch-ed }\end{array}$ & $\begin{array}{l}\text { Town } \\
\text { Hous } \\
\text { e }\end{array}$ & $\begin{array}{l}\text { Clust } \\
\text { er }\end{array}$ & $\begin{array}{l}\text { Low- } \\
\text { Cost } \\
\text { Hous } \\
\text { e }\end{array}$ & $\begin{array}{l}\text { Low } \\
\text { Cost } \\
\text { Flat }\end{array}$ & Flat & $\begin{array}{l}\text { Servi } \\
\text { ce } \\
\text { Apart } \\
\text { ment }\end{array}$ & $\begin{array}{l}\text { Condo/ } \\
\text { Apartm } \\
\text { ent }\end{array}$ \\
\hline $\begin{array}{r}21,57 \\
4\end{array}$ & $\begin{array}{r}65,94 \\
1\end{array}$ & 466 & 5,956 & 7,092 & 4,671 & 4,248 & 3,786 & $\begin{array}{r}95,64 \\
7\end{array}$ & $\begin{array}{r}50,15 \\
6\end{array}$ & $\begin{array}{r}23,69 \\
4\end{array}$ & 157,465 \\
\hline \multicolumn{12}{|c|}{ 440,696 (Total) } \\
\hline
\end{tabular}


Housing typology in Kuala Lumpur area can generally be differentiated by suburban or urban (city centre) areas. Most common housing typology in suburban areas of Kuala Lumpur are such as walk-up low-density apartments (or town house or clusters), detached houses (semi-detached or single bungalow) and terrace (or link) houses (Ju \& Omar, 2011). Most of the suburban housing typology is built with pitch roof and wide openings for cross ventilation purposes, and the materials used are usually reinforced concrete (Ju \& Omar, 2011). Refer Figure 1 for example of walk-up low-density apartment and Figure 2 for a 2 storey semi-detached housing.

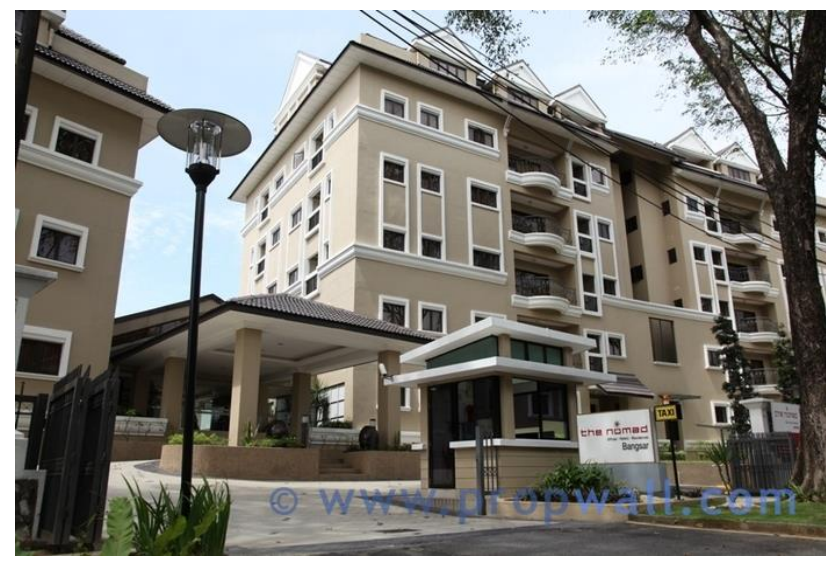

Figure 1: Walk-up Low-density Apartment Figure 2: Detached Housing (Semi Detached)

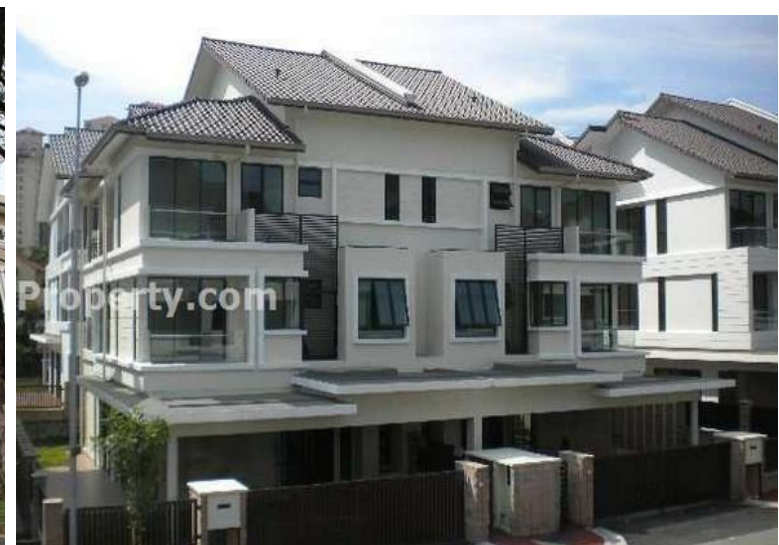

Source: iProperty (2015a)

In the city centre or urban areas of Kuala Lumpur, the most common housing typology are the condominiums and apartments. The condominiums and apartments in the city centre are usually high-density and high-rise, and some provide full serviced apartments to cater for international expatriate working in the city centres. Refer Figure 3 for an example of a high-rise high-density luxury apartment, The Troika and Figure 4 for an example of a highrise serviced apartment, One KL. 


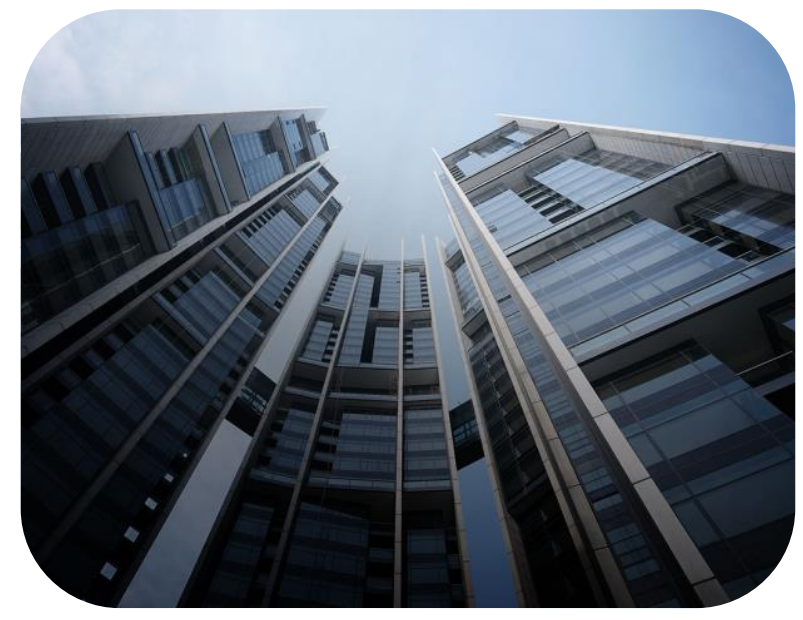

Figure 3: High-Rise High-Density Apartment Source: BRDB (2010)

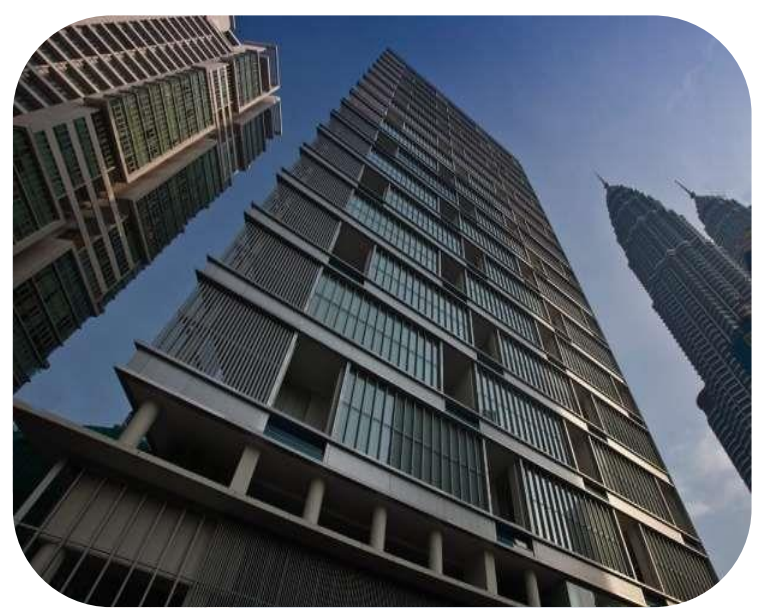

Figure 4: Serviced Apartments

Source: iProperty (2015b)

\section{$3 \quad$ Housing Affordability}

Urban housing has become a major concern for many governments and state authorities due to the unprecedented growth of the urban population. Carole Rakodi (1992) argued that the housing problem cannot be solved with a capitalist economic system because of structural restrictions to employment and income availability for the poor majority remains very limited and only advances the richer society. $\mathrm{Ha}$ (2004) provides a definition to housing poverty, which means "the basic problems of housing shortage, poor physical conditions and overcrowding; and the ability of households to gain access to suitable dwellings." He also suggests that countries should attempt to define a minimum standard of dwelling type, choice and mobility into housing policies.

The provision of affordable housing is unable to keep pace with and to meet demands of the growing poor population in many urban areas, this is due to many contributing factor like the growing influx of rural poor population migrating to the city. The increase of urban poor population is just natural population growth within these cities (Goran \& Ljung, 2006). Affordable housing has been a problem for governments and lower income population for decades in time, and even as we progress technologically or into modernity, it does not seem to decrease in intensity. As Charles Abrams (1964) implied:

"The technical genius that broke the secret of speed, sound and space and light can't build a house cheap enough for the rank and file. A cosmonaut can orbit the world; the State that launched him can't establish a good housing programme on the ground. The more the country develops industrially, the more stubborn the housing problem becomes." (Abrams, 1964) 
Therefore methods of producing affordable housing needs to be re-evaluated to better serve the majority poorer population. With the steady increase of demand for low-cost housing in Malaysian urban areas, it is worthwhile to investigate the current policies related to public low-cost housing. Therefore this paper aims to inform policy makers in terms of the effectiveness of PPR low-cost housing projects in the long-term operational affordability, looking at the urban area of Kuala Lumpur where living costs are high. However this paper is limited to existing households in selected PPR low-cost housing projects as in a case study context, and assumes that each household had met the eligibility criteria set by the government in allocating such PPR low-cost housing units. A survey questionnaire ${ }^{\text {ii }}$ was conducted to determine what percentage of household income is spent on rent/housing loan repayment, electricity and water. Measuring household electricity bills and monthly household income provides the proportion spent on electricity, as an indicator of operational and long-term affordability.

According to Bujang (2006) and Zebardast (2006), housing affordability can be defined by the ratio of household income to the monthly housing loan payment or rent, which is less than $30 \%$ of its monthly income (Bujang, 2006; Zebardast, 2006). This housing affordability definition often overlooks other important issues such as environmental and social sustainability of housing (Mulliner et al., 2013), where a typical low-income household spends a substantial share of monthly income on energy and utility services such as electricity, heating and water (Fankhauser and Tepic, 2005; Fankhauser and Tepic, 2007).

Conversely, according to the international benchmark for housing affordability, average housing expenditure can be further disaggregated to electricity $(10 \%)$, heating $(12 \%)$, and water (3.6\%) (Fankhauser and Tepic, 2007). A comparison of other international data on household expenditure for utilities to percentage of income, to calculate an approximate average of household income percentage spent on different utilities such as fuels, water and other utilities, and is compiled in Table 2 (Australian Bureau of Statistics, 2011; Department of Statistics, 2011a; Central Bank of Malaysia, 2010; ILO, 2010; Ministry for the Environment, 2009; Department of Statistics Singapore, 2008; Fankhauser \& Tepic, 2007). Hence, definition of operational affordability for housing in this paper will consist of the percentage of monthly housing loan payment/rent and the operational costs of electricity and other utilities, defined in terms of percentage of household expenditure to monthly income:

- less than $30 \%$ for rent/housing loan repayment;

- less than $10 \%$ for electricity; and

- less than $6 \%$ for other utilities (including water, telephone, internet, etc). 
Table 2 Household Average Monthly Percentage of Utilities Expenditure to Monthly Income ${ }^{1}$

\begin{tabular}{|l|l|l|l|}
\hline $\begin{array}{l}\text { \% of Average Household } \\
\text { Income }\end{array}$ & $\begin{array}{l}\text { Fuel } \\
\text { (Electricity and other } \\
\text { fuels) }\end{array}$ & Water Utility & $\begin{array}{l}\text { Other Utilities } \\
\text { (including } \\
\text { telephone, } \\
\text { postal, internet, } \\
\text { etc) }\end{array}$ \\
\hline $\begin{array}{l}\text { International Labour } \\
\text { Organization (ILO) }\end{array}$ & $6.6 \%$ & $\begin{array}{l}3.4 \% \\
\text { (communications } \\
\text { only) }\end{array}$ \\
\hline $\begin{array}{l}\text { World Bank (2004) } \\
\text { (from Fankhauser \& Tepic, } \\
2007\end{array}$ & $10-15 \%$ & $-3.3 \%$ & - \\
\hline $\begin{array}{l}\text { World Health Organization } \\
\text { (WHO) (2004) (from } \\
\text { Fankhauser \& Tepic, 2007 }\end{array}$ & $10 \%$ & $3-5 \%$ & - \\
\hline $\begin{array}{l}\text { IPA Energy (2003) } \\
\text { (from Fankhauser \& Tepic, } \\
2007\end{array}$ & $10 \%$ & - & - \\
\hline $\begin{array}{l}\text { United Kingdom Government } \\
\text { (from Fankhauser \& Tepic, } \\
2007\end{array}$ & - & $3 \%$ & - \\
\hline $\begin{array}{l}\text { United States Government } \\
\text { (from Fankhauser \& Tepic, } \\
2007\end{array}$ & - & $2.5 \%$ & - \\
\hline $\begin{array}{l}\text { Asian Development Bank } \\
\text { (2003) } \\
\text { (from Fankhauser \& Tepic, } \\
2007\end{array}$ & - & $5 \%$ & $\begin{array}{l}\text { (communication } \\
\text { only) }\end{array}$ \\
\hline Malaysia (2010) & $19 \%$ (housing, water, electricity) & $\begin{array}{l}\text { (communications } \\
\text { only) }\end{array}$ \\
\hline Australia (2009) & $28.2 \%$ (housing, water, electricity) & - \\
\hline New Zealand (2009) & $13.1 \%$ & $11.1 \%$ & $-6 \%$ \\
\hline
\end{tabular}

\footnotetext{
${ }^{1}$ It is noted that these benchmark are only an assumed comparison, at an international level, which have not taken into consideration of household income, climate and other social and/or economic variation.
} 


\begin{tabular}{|l|l|l|l|}
\hline & & \multicolumn{2}{|l|}{ (telephone, water, etc) } \\
\hline Singapore (2008) & $2.8 \%$ & $2.8 \%$ iv & $\begin{array}{l}4.8 \% \\
\text { (communication } \\
\text { only) }\end{array}$ \\
\hline \hline Total \% & $57.5 \%$ & $49.8 \%$ & \\
\hline Average \% & $9.6 \% \vee$ & $5.5 \%$ & \\
\hline
\end{tabular}

According to the Kuala Lumpur Structure Plan 2020, the term 'affordable housing' includes low, low-medium and medium-cost housing with a selling prince between RM 42,000 to RM 150,000 per unit. It is targeted for the low and medium income population with a monthly household income of RM 1,500 to RM 4,000 a month (DBKL, 2000). The report further defines low-cost, low-medium-cost and medium-cost housing as:

- Low-cost housing as a house with selling price between RM 25,000 to RM 42,000 per unit, with a minimum floor space of 650 square feet;

- Low-medium-cost housing as a house with selling price between RM 42,001 to RM 85,000 per unit; and

- Medium-cost housing as housing with selling price between RM 85,001 to RM 150,000 per unit.

Based on these definitions, urban low-cost housing in Malaysia can be categorized as housing which is more than 5-storey high, with a minimum floor space of 650 feet, and for a ceiling sale price of $\mathrm{RM} 42,000$.

\section{Definition of public PPR low-cost housing in Malaysia}

This paper is concerned with public low-cost housing under the National Economic Action Council (NEAC) People's Housing Programme or Program Perumahan Rakyat (PPR)vi. The PPR is the national standard of public low-cost housing projects, coincidently significant in its percentage of construction. According to the Ninth Malaysia Plan, public low-cost housing represented approximately 192,000 units (31\%) of Malaysian's annual housing target between 2001-2005 (EPU, 2006). However the actual low-cost housing units built by the public sector between 2006-2010 dropped to only 85,000 units per year, representing $27.9 \%$ total housing) (EPU, 2006).

The housing industry's typical mode of delivery is the "sell then build" (STB) that has been practiced for decades long, which allows developer to sell houses based on brochures and scaled models before building them (Fen, 2007; Yusof et al., 2010). This model has raised many issues and grievance to home-buyers who had to endure substandard workmanship, 
late delivery of houses and abandoned projects (Fen, 2007; Yusof et al., 2010). In 2006 the government announced a new delivery system, the "build then sell" (BTS) to running concurrently with the traditional STB system for a trial period of 2 years, in order to help resolve these issues (Fen, 2007; Yusof et al., 2010).

Subsequently in the Tenth Malaysia Plan (2011-2015), a total of 95,800 low-cost housing units were built during the Ninth Malaysia Plan (2006-2010) (EPU, 2010). Approximately 42,300 units of low-cost housing (44.2\%) were built by the public sectorvii and 53,500 units (55.8\%) built by the private sector (EPU, 2010). However, based on a nation-wide States government census, as of $30^{\text {th }}$ June 2010 , there were 90,282 squatter households that had not been relocated (National Housing Department, 2011).

This exemplifies insufficient provisions by both the public and private sector to meet the growing demand for low-cost housing, and the importance of low-cost housing within the residential context. This growing demand is due to a growing urban population, where the housing market is extensive and purchasing power is higher than rural areas (National Housing Department, 2011). The rising demand is also reflected in the new 2013 Federal

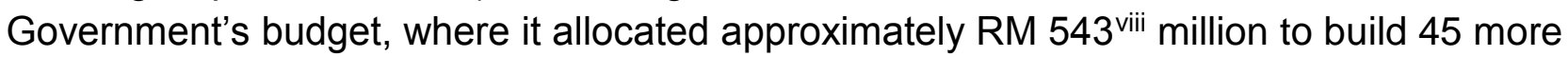
urban PPR housing project across the country (Mustafa, 2012).

Public low-cost housing units are subsidized between 30 to $70 \%$ of the total construction cost by the government (EPU, 2010). Low-cost housing in Malaysia is also seen as a mandatory section of housing development, as housing developers must provide $30 \%$ of their total housing development for low-cost housing (EPU, 2006; REHDA, 2008; Wan Abd Aziz, 2007). Administrative procedures force developers to set aside a portion of the development project to provide low-cost housing in order to gain development approval by local authorities. However, the process has had the unintended consequence of leading to the questionable quality of these low-cost housing completions (REHDA, 2008; Wan Abd Aziz, 2007). Low quality of construction for 'affordable' or low-cost housing has been identified as a key issue in the Tenth Malaysia Plan and the National Housing Policy (EPU, 2006; National Housing Department, 2011).

Specifically, low-cost housing in Kuala Lumpur is targeted at households earning less than RM 4,000 per month, while other urban areas in Malaysia is targeted at household earning less than RM 1,500 per month (City Hall of Kuala Lumpur, 2009b; National Housing Department, 2008). Urban low-cost housing in Kuala Lumpur can also be defined as housing that is over five store high, for a maximum sale price of RM 42,0004, or rented out at RM 124.00 per month, for households earning less RM 4,000 a month (City Hall of Kuala Lumpur, 2009b; National Housing Department, 2008).

According to the Central Bank of Malaysia, households in 2010 spend approximately 19\% of household income for the combination of "housing, water, electricity, gas and fuels" 
(Central Bank of Malaysia, 2010). Similarly, the average monthly household expenditure published by Department of Statistics Malaysia also combined expenses for housing, water, electricity, gas and other fuels, which calculated an increase of expenditure by 15.1\% for 2010 from 2005 (Department of Statistics, 2010). Other high percentages of household expenditure include food and non-alcoholic beverages (23\%), transport (13.4\%), and miscellaneous goods and services (12.8\%) (Central Bank of Malaysia, 2010). Other utility expenses such as telephone and internet should also be included while determining affordability to keep up with current demands and changing housing needs (Litman, 2013; Smith, 2010). An average of $6 \%$ of household income was spent on communication services (i.e. telephone, and postal services) (Central Bank of Malaysia, 2010).

\section{Effectiveness of PPR low-cost housing projects - Affordable and Sustainable Urban Housing?}

The subject of sustainable low-cost housing has not been the focus of policy makers in Malaysia. In relation to the triple-bottom-line approach of sustainability, elements of environmental, economic and social dimensions are the starting point (Pope et al., 2004). Past research into low-cost housing in Malaysia mainly focused on post occupancy evaluation, in terms of satisfaction level of dwelling unit features, surrounding services and utilities, social and neighbourhood environment (see Khair et al., 2012; Mohit et al., 2010; Omar, 2008; Salleh, 2008; Sulaiman and Yahaya, 1987). There is a clear gap in environmental research for this specific residential typology in Malaysia. However, this paper is limited to reporting only on the economic and social features of sustainability of PPR low-cost housing projects in Malaysia.

The Malaysian construction industry has always played an important role in the country's economic and social development, providing approximately $8 \%$ of total workforce annually (CIDB, 2007). In 2011, the Malaysian construction industry contributed approximately $3 \%$ to the national Gross Domestic Product (GDP), with an annual growth of 4.6\% (Department of Statistics, 2011). However, poor quality of construction, maintenance and performance of contractors remain the central challenges affecting the industry (EPU, 2010; Hamid and Kamar, 2010). The current low construction quality of housing is recognized in the National Housing Poolicy as a major challenge to the industry (National Housing Department, 2011), as many developments still do not meet the minimum standard requirements (EPU, 2010). This is due to weaknesses in implementation of the building regulations and enforcing related legislation. Poor quality is also highly dependent on unskilled and cheap foreign labour (National Housing Department, 2011).

The National Housing Policy (NHP) was introduced in 2011 as a guideline to provide adequate quality and affordable housing to all relevant stakeholders at the federal, state, local and private sector levels (National Housing Department, 2011). One of the National Housing Policy's objectives is to set the "future direction to ensure the sustainability of the 
sector" (National Housing Department, 2011). Two other objectives set in the housing policy are to provide "adequate and quality housing with comprehensive facilities and a conducive (living) environment" and to enhance "the capability and accessibility of the people to own or rent houses" (National Housing Department, 2011).

Additionally, the Malaysian construction industry has yet to streamline and modernize its approach to innovative building systems and energy efficiency (Hamid and Kamar, 2010). For example, the Construction Industry Development Board (CIDB) missed an opportunity to promote energy efficiency in the Construction Industry Master Plan (2006-2015), which was launched in 2007 (CIDB, 2007). Hamzah (2012) also recently revealed that there are numerous overlapping requirements in Malaysia's legislation, for instance zoning provisions, which fall under both the National Land Code and the Town, and Country Planning Act, has caused a non-standard requirement that is addressed on a case-by-case basis. Housing developers consequently perceive this flexibility and non-standard procedure as manipulation of the regulations that could lead to corruption (Hamzah, 2012).

\section{Methodology}

A survey questionnaire was conducted to determine what percentage of household income is spent on rent/housing loan repayment, electricity and waterix. Measuring household electricity bills and monthly household income provides the proportion spent on electricity, as an indicator of operational and long-term affordability. A short-listed and pre-coded questionnaire with pre-determined answers was considered as the most appropriate method (Buckingham and Saunders, 2004) to investigate operational affordability of PPR low-cost housing projects, as it increases the reliability of the data collected.

A face-to-face approach was deemed most suitable for conducting the questionnaire, as it encourages a faster response rate through a random sampling technique (Buckingham and Saunders, 2004; Preston, 2009) that also filters out unwilling respondents. Additionally, to reduce and avoid biased answers, the questionnaire included multiple choices based on a range of monthly household income scaled from under RM 1,500 to RM 4,000 or more per month and monthly household expenditure for electricity and other amenities between RM 150 to RM 400 or more per month.

The existing total number of PPR low-cost housing units in Kuala Lumpur is 27,102 units (as of 2009), which represents the case study's population size (City Hall of Kuala Lumpur, 2009a). Therefore, the sample size can be determined for this case study context. Calculation for the sample size is determined by using the following statistical classification: confidence level of $90 \%$, confidence interval of 0.05 (or $+/-5 \%$ ) and percent defects of $50 \%$ (or split 50/50 response distribution). The minimum sample size was calculated at 266 household units, for the population of 27,102. 
The survey questionnaire collected data from a total of 281 household units from two PPR low-cost housing projects in Kuala Lumpur, namely PPR Beringin (129 units) and PPR Intan Baiduri (152 units). The two PPR low-cost housing projects were selected as the two most representative characteristics of average PPR low-cost housing projects in Kuala Lumpur, which consisted of 1,130 apartment units, 4 building blocks and 17 storey height (City Hall of Kuala Lumpur, 2009a). The survey was conducted over approximately 11 weeks between December 2011 and March 2012.

\section{$4 \quad$ Findings and Analysis}

The case study found that most households earned between RM 1000 to RM 2500 a month, with a combined average of $60.5 \%$ of the sample size. Some $20.2 \%$ of households earned between RM 1000 to RM 1500 a month, $23.6 \%$ of households between RM 1500 to RM 2000 a month, and 16.7\% earned between RM 2000 to RM 2500 a month (refer Figure 5). Therefore, if most households earn between RM 1000 to RM 2500 a month, $30 \%$ of this range would be approximately between RM 300 to RM 750 a month (for rent), while $10 \%$ of household earnings would provide a range between RM 100 to RM 250 a month for electricity. Additionally, affordability for combined operational costs of electricity and other utilities is defined as less than $25 \%$ of total household income. To simplify, the following is presented:

- $30 \%$ of RM 1000 to $\mathrm{RM} 2500=\mathrm{RM} 300$ to $\mathrm{RM} 750$ for rent

- $10 \%$ of RM 1000 to RM $2500=$ RM 100 to RM 250 for electricity

- $6 \%$ of RM 1000 to RM $2500=$ RM 60 to RM 150 for other utilities

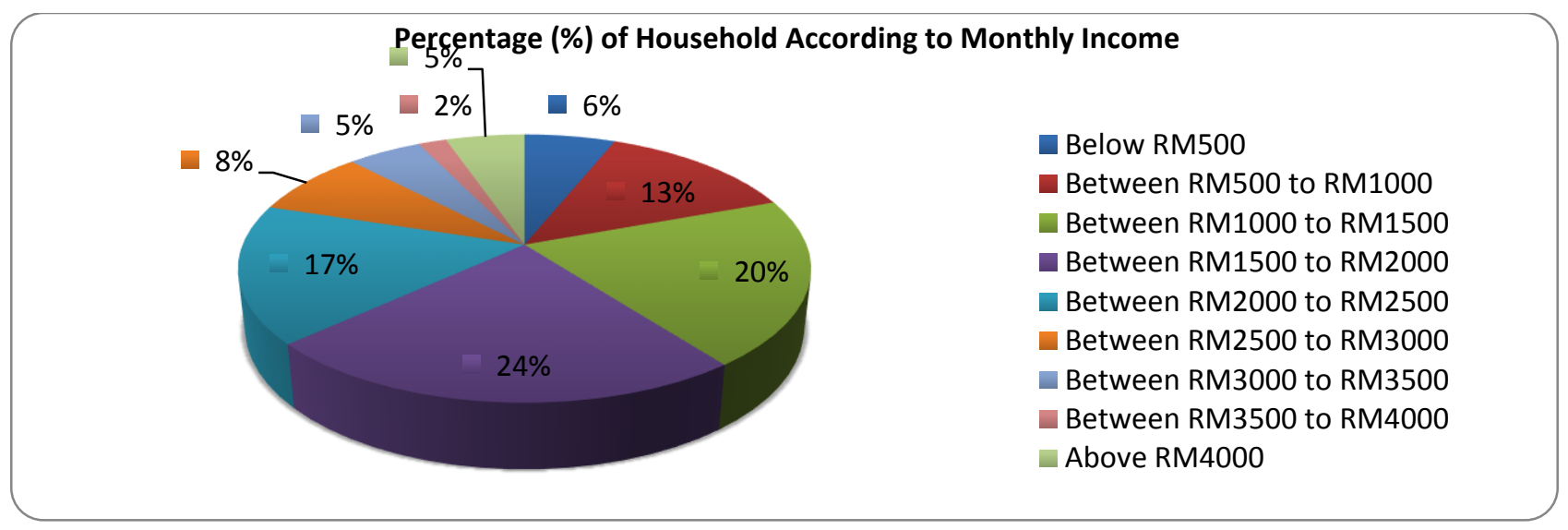

Figure 5 Average Household Monthly Income $(n=281)$

\subsection{Monthly Rent or Housing Loan Repayment}


The majority of households spend an average of RM 100 to RM 150 monthly for rent or housing loan repayments or $88 \%$ of total households surveyed. This reflects the low monthly rental set by the Ministry of Housing and Local Government, at RM 124 per month. If the average household is assumed to earn approximately RM 1500 a month (middle range between RM 1000 to RM 2000) and is compared with the standardized rent of RM 124 a month, only $8.3 \%$ of monthly household income is spent on rent. However, there were also a percentage of households that did not have any housing expenditure due to special considerations, represented at $11.3 \%$ of total sample size.

There were a small percentage of households (0.75\%) that spend more than RM 300 a month on rent or housing loan repayments. The remaining households either spend less than RM 50 monthly for rent or housing loan repayment $(0.4 \%)$, or between RM 150 to RM 300 a month (1.05\%). Therefore about $88 \%$ of households spend less than RM 300 monthly on rent or housing loan repayment, which is lower than the $30 \%$ affordability range of monthly household income and is presented in a pie chart to further illustrate the findings (refer Figure 6).

Average Percentage (\%) of Monthly Income Spent for Rent/Housing Loan Repayment

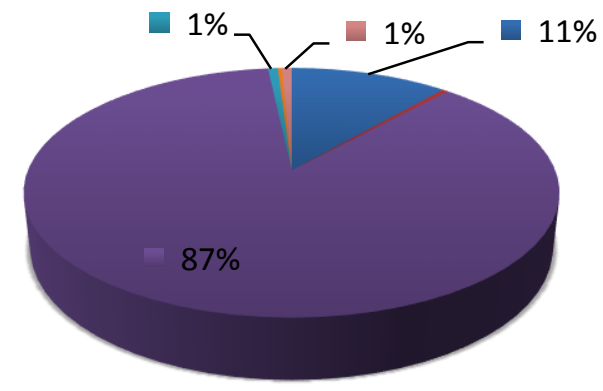

N/A

- Below RM50

- Between RM50 to RM 100

- Between RM100 to RM150

- Between RM150 to RM200

- Between RM200 to RM250

- Between RM250 to RM300

Above RM300

Figure 6 Average Household Monthly Rent/Housing Loan Repayment ( $n=281)$

\subsection{Monthly Electricity and Other Utilities Expenditure}

Based on the survey findings, the majority of households (85\%) spend no more than RM 100 per month on electricity. About $44 \%$ of households spend less than RM 50 a month and $41 \%$ spend between RM 50 to RM 100 a month on electricity. Therefore, a combined average of approximately $98 \%$ of households surveyed spends no more than RM 200 a month on electricity. In comparison with the average household income range of RM 1000 to RM 2500 a month, 10\% affordability should lie between RM 100 and RM 250 a month. This suggests that electricity is affordable for the sample size surveyed. 
However, there is a small percentage of $0.8 \%$ of households where electricity expenditure information was not available, or was not applicable to the household under special considerations 83 . The remaining $1 \%$ of households spends more than RM 250 a month on electricity while $0.7 \%$ of households spend between RM 250 to RM 300 and $0.3 \%$ spends above RM 300 a month. Thus a small number of households exceed the $10 \%$ international affordability standard of RM 100 to RM 250 for monthly electricity. This is also presented in a pie chart to further illustrate the findings (refer Figure 7).

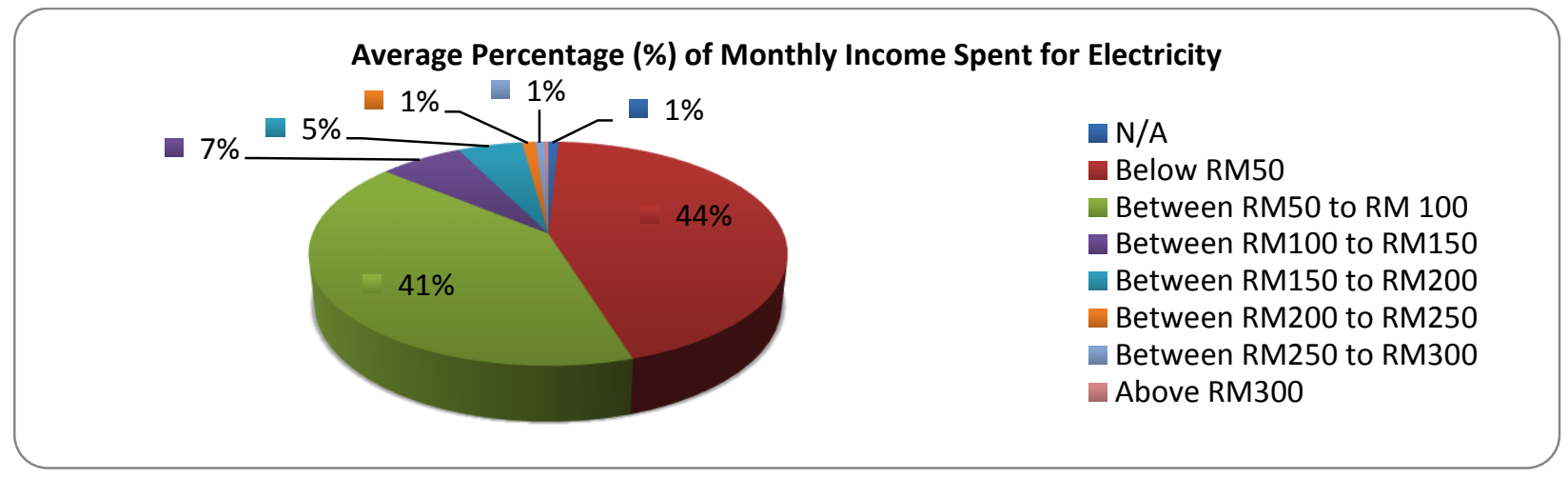

Figure 7 Average Household Monthly Electricity Expenditure $(n=281)$

Subsequently, it was found that $79 \%$ of households spend less than RM150 a month on other utilities. Other utilities in this context refer to facilities such as water, telephone, Internet and/or satellite (cable) television bills. The remaining $21 \%$ of households spend either between RM 150 to RM 300 a month (20\%) or more than RM 300 a month (1.1\%) for other utilities. The international average of other utilities expenditure is $6 \%$ of household income (Australian Bureau of Statistics, 2011; Department of Statistics, 2011a; Central Bank of Malaysia, 2010; ILO, 2010; Ministry for the Environment, 2009; Department of Statistics Singapore, 2008; Fankhauser \& Tepic, 2007). The findings suggests that majority of households (79\%) spend less than $6 \%$ of household income for other utilities. This is also presented in a pie chart to further illustrate the findings (refer Figure 8).

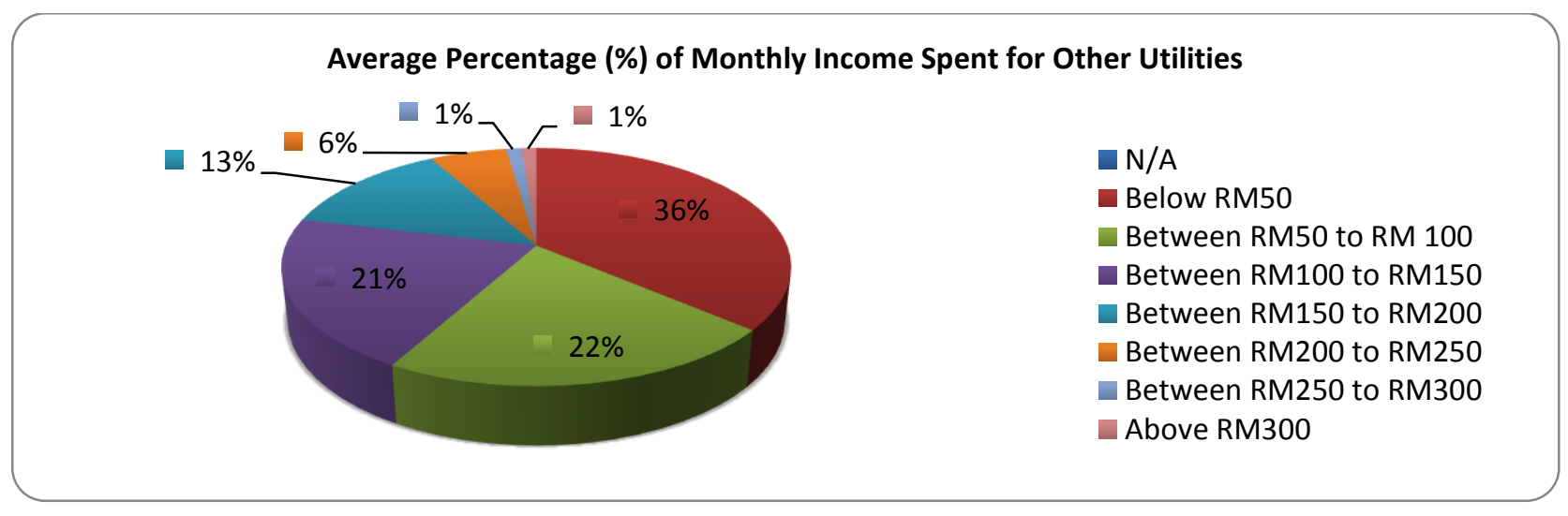

Figure 8 Average Household Monthly Other Utilities Expenditure $(n=281)$ 


\section{Summary of Analysis}

In summary, the average household income was established at RM 1000 to RM 2500 a month for the majority $(61 \%)$ of households surveyed. Thirty per cent of this range is between RM 300 and RM 750 a month for rent or housing loan repayment, which is defined as affordable. The range of monthly rent or housing loan repayment was lower than the $30 \%$ affordability standard, where the majority of households (88\%) spend between RM 100 to RM 150 a month. The RM 100 to RM 150 range is approximately $6 \%$ to $10 \%$ of average household monthly income. Another $0.75 \%$ of households spent more than RM 300 a month for rent or housing loan repayment. Therefore it can be concluded that for majority of households (88\%), the PPR housing units are affordable in terms of their rent or housing repayment expenditure.

The standard of affordability for electricity expenditure was set at $10 \%$, according to the international benchmark (Fankhauser \& Tepic, 2007; Bujang, 2006; Zebardast, 2006). It represents RM 100 to RM 250 of average monthly household income. It was found that $98 \%$ of total households spent less than RM 250 a month for electricity. The average household expenditure for electricity can be assumed to be approximately RM 50 a month, based on the information provided by respondents of the household surveyed, not actual electricity bills. This assumption is reflected by the two highest percentages of household expenditure on electricity, i.e. less than RM 50 a month (44\%), and between RM 50 to RM 100 a month (41\%). Therefor the case study findings suggest that electricity is affordable for the majority of households in the PPR housing projects, as the low tariff rates are maintained.

In terms of other utilities including water, telephone, internet and satellite (cable) television bills, approximately $79 \%$ of households spend less than $6 \%$ of average household income on these services. The other $20 \%$ spends between RM 150 to RM 300 a month, and remaining $1 \%$ spends more than RM 300 a month. The average household expenditure for other utilities can be assumed to be approximately RM 50, also reflected by the two highest percentages of household expenditure on other utilities, i.e. less than RM 50 a month (36\%), and between RM 50 to RM 100 a month (22\%).

Therefore, in calculating the average combined expenditure for both electricity and other utilities, the total would be approximately RM 100 a month. This consequently shows that the combined operational costs for electricity and other utilities is approximately $10 \%$ of average household monthly income (refer Table 3). These analyses are also presented on a bar chart to better illustrate the conclusions (refer Figure 9). 


\begin{tabular}{|c|c|c|c|}
\hline \multicolumn{4}{|c|}{$\begin{array}{l}\text { Apportionment of Operational Cost (\%) to Average Monthly Household Income of } \\
\qquad \text { RM } 1,000 \text { to RM } 2,500\end{array}$} \\
\hline & $\begin{array}{l}\text { International } \\
\text { Benchmark }\end{array}$ & Survey Findings & $\begin{array}{c}\text { Average } \\
\text { Operational } \\
\text { Expenditure }\end{array}$ \\
\hline Rent & $\begin{array}{c}30 \% \\
\text { (RM } 300 \text { to RM } \\
750)\end{array}$ & $\begin{array}{c}<\text { RM } 300(89 \%) ; \\
\text { > RM } 300(0.8 \%) ; \\
\text { N/A }(11 \%)\end{array}$ & $\begin{array}{l}\text { RM } 100 \text { to } \mathrm{RM} 150 \\
(89 \%)\end{array}$ \\
\hline Electricity & $\begin{array}{c}10 \% \\
(\mathrm{RM} 100 \text { to } \mathrm{RM} \\
250)\end{array}$ & $\begin{array}{c}<\text { RM } 250(98 \%) \\
>\text { RM } 250(1 \%) \\
\text { N/A }(0.8 \%)\end{array}$ & $\begin{array}{l}<\mathrm{RM} 50 \text { to } \mathrm{RM} 100 \\
(85 \%)\end{array}$ \\
\hline $\begin{array}{l}\text { Other Utilities } \\
\text { (Water, } \\
\text { telephone bills, } \\
\text { internet, } \\
\text { satellite } \\
\text { television) }\end{array}$ & $\begin{array}{c}6 \% \\
\text { (RM } 60 \text { to } \mathrm{RM} \\
150)\end{array}$ & $\begin{array}{c}\text { < RM } 150(79 \%) ; \\
\text { RM } 150 \text { to RM } 300 \\
(20 \%) ; \\
\text { > RM } 300(1 \%) ; \\
\text { N/A }(0 \%)\end{array}$ & $\begin{array}{l}<\text { RM } 50 \text { to } \mathrm{RM} 100 \\
\qquad(58 \%)\end{array}$ \\
\hline
\end{tabular}

Table 3 Analysis of Operational Affordability

Figure 9 illustrates the combined survey findings data, in terms of percentage (\%) of households surveyed (Axis $\mathrm{Y}$ ), for average monthly income and proportioned operational expenditure for rent/housing loan repayment, electricity and other utilities (Axis X). Figure 9 further indicates the majority (61\%) household's average monthly income of RM 1,000 to RM 2,500 (marked in dotted line and labelled 'Average Household Income Range'). The bar chart is further manipulated to indicate where $10 \%$ of the average monthly household income range would be located in the proportioned operational expenditure of rent/housing loan repayment, electricity and other utilities (marked in dotted line and labelled ' $10 \%$ of Average Household Income Range'). This consequently illustrates that the majority of household's monthly operational expenditure lies within, or less than the $10 \%$ of the average household income range. The data for percentage (\%) of household's operational expenditure lying within $10 \%$ of the average household income range is also presented in Table 3. 


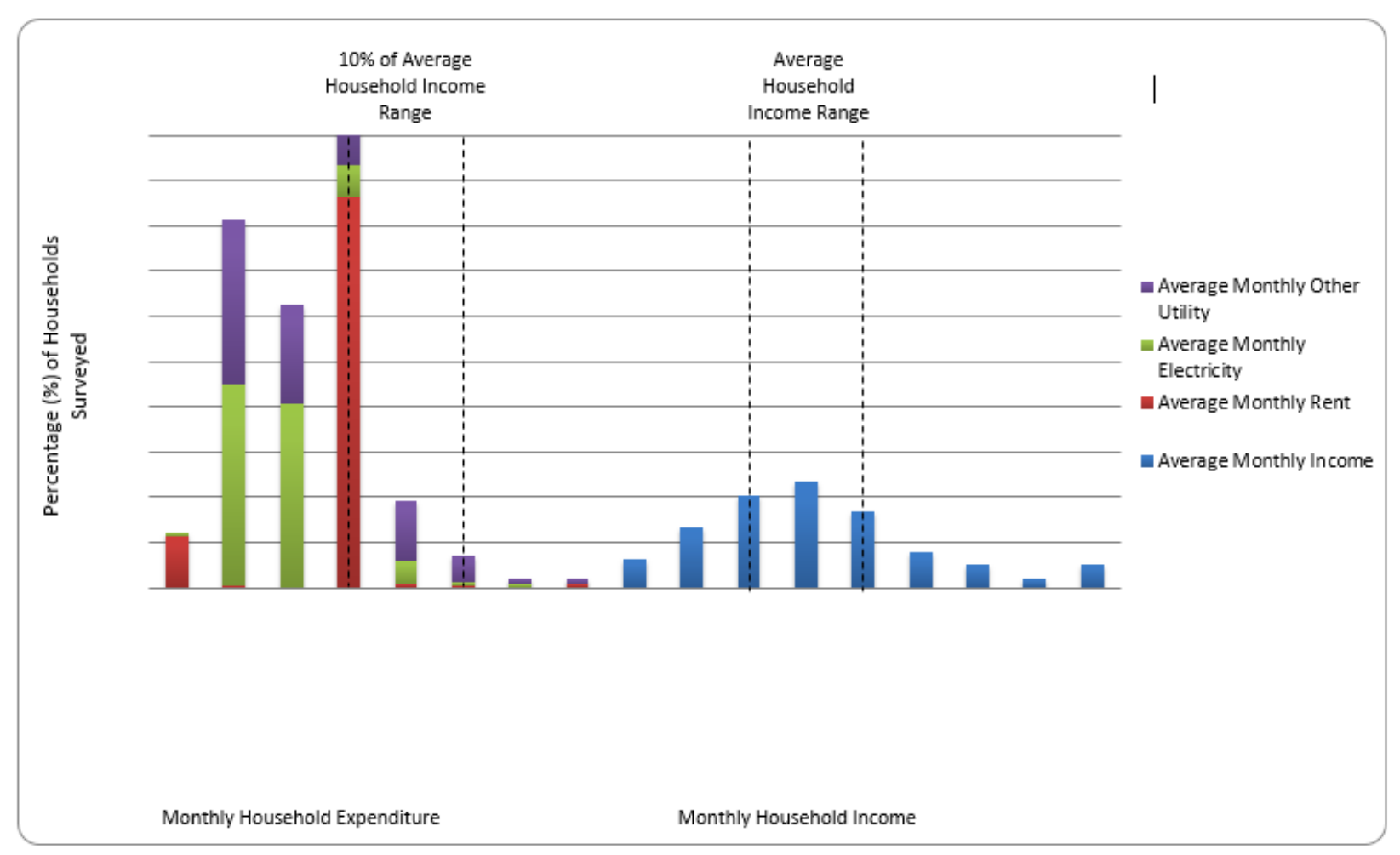

Figure 9 Percentages of Average Household Monthly Expenditure and Income

\section{$6 \quad$ Conclusions and Recommendations}

Based on this analysis, the percentage associated with energy and other utility costs is within the range of the international average of $10 \%$ and $6 \%$ of household income, respectively (Australian Bureau of Statistics, 2011; Department of Statistics, 2011a; Central Bank of Malaysia, 2010; ILO, 2010; Ministry for the Environment, 2009; Department of Statistics Singapore, 2008; Fankhauser \& Tepic, 2007). Additionally, in calculating the combined average expenditure for both electricity and other utilities, the mode was calculated to be approximately RM 100 a month. This consequently shows that the combined operational costs for electricity and other utilities is approximately $10 \%$ of average household monthly income. Similarly, most households spends at average $10 \%$ of their household income for rent or housing loan repayment, which is lower than the international benchmark of $30 \%$ of household income.

This research is limited to only presenting operational costs of rent/housing loan repayment, electricity and other utility bills such as water, telephone, internet and/or satellite (cable) television. Therefore this gap presents an opportunity for further research to include such household expenses in investigating true operational affordability for the 
low-income households in public low-cost housing projects. Such investigation should also be conducted nationwide in a long-term period, and at intervals to reflect current costs of living and living standards. In conclusion, the research has presented a snap shot of empirical data on household survey in terms of operational affordability for public low-cost housing in Malaysia.

Additionally, other household expenses such as education, health, transportation and so forth were not investigated. Therefore this gap presents an opportunity for further research to include such household expenses in investigating true operational affordability for the low-income households in PPR low-cost housing projects. Such investigation should also be conducted nationwide in a long-term period, and at intervals to reflect current costs of living and living standards.

As Malaysian households enjoy highly subsidized electricity services, there is high risk of direct-rebound effect, which is presently not being investigated. Therefore, further research in the affordability of electricity can also be used as a mechanism to gauge the occurrence of any rebound effect in comparison to other developing countries with similar characteristics of electricity consumption and household income. Collaborative findings could inform policies, in terms of reallocating subsidies for designated electricity. Strong linkages between energy use, health, social development and environmental impacts should be addressed in energy distribution policies, in order to assess long-term effects of subsidy policies.

\section{Bibliography}

Abrams, Charles 1964. Man's Struggle for Shelter in an Urbanizing World. Cambridge: The MIT Press

Aziz WNAWA 2007 Low-Cost Housing Policy in Malaysia: The Challenge of Delivery. School of Town and Regional Planning. vol. PhD. University of Dundee: Dundee; 2007.

BRDB 2015 The Design of The Troika. Downloaded from http://www.brdb.com.my/portfolio/residential/troika/features.asp?sb=thedesign

Buckingham A, Saunders P The Survey Methods Workbook. Polity Press Ltd. : Cambridge, UK; 2004.

Bujang AA 2006 Housing Ownership: An Evaluation Study on the Bumiputera Quota Lot Rules in the District of Johor Bahru. Property Management. vol. PhD. University of Malaya: Kuala Lumpur; 2006.

Central Bank of Malaysia 2010. The Growth and Evolution of Consumer Spending in Malaysia. Annual Report 2010. Central Bank of Malaysia (Bank Negara Malaysia): Kuala Lumpur; 2010.

CIDB 2007 Construction Industry Master Plan Malaysia 2006 - 2015. Construction Industry Development Board (CIDB) Kuala Lumpur; 2007.

City Hall of Kuala Lumpur 2009a. Housing Management Department Bulletin. May Edition. Housing Management Department

City Hall of Kuala Lumpur 2009b. PPR Home Sales. City Hall of Kuala Lumpur; 2009b. 
Department of Statistics 2010 Household Expenditure Trends 1993 to 2010. Department of Statistics Malaysia; 2010.

DBKL 2000. Kuala Lumpur Structure Plan 2020. Kuala Lumpur: Dewan Bandaraya Kuala Lumpur (Kuala Lumpur City Hall ). Accessed at http://www.dbkl.gov.my/pskl2020/english/

Department of Statistics 2011. National Accounts - Gross Domestic Product. Monthly Bulletin - November 2011. Department of Statistics Malaysia: Putrajaya, Malaysia 2011.

Department of Statistics Singapore 2008 Report on the Household Expenditure Survey, 2007/08. Publication Catalogue. Department of Statistics Singapore, Government of Singapore: Singapore; 2008.

EPU 2006 Ninth Malaysia Plan (2006-2010). In: P. M. s. Department, (Ed). The Economic Planning Unit: Putrajaya; 2006.

EPU 2010 Tenth Malaysia Plan. Economic Development: Development Plans. Economic Planning Unit; 2010.

Fankhauser S, Tepic S 2005. Can poor consumers pay for energy and water? An affordability analysis for transition countries. Working paper No. 92. European Bank for Reconstruction and Development (EBRD): London, United Kingdom; 2005.

Fankhauser S, Tepic S 2005. Can poor consumers pay for energy and water? An affordability analysis for transition countries. Energy Policy 2007; 35; 1038-1049.

Fen, N.L. 2007. Determinant Factors of Implementing Build then Sell in Malaysia: Housing Developers Point of View. Masters of Project Management, Universiti Sains Malaysia.

Goh AT, Yahaya A. 2011 Public Low-Cost Housing in Malaysia: Case Studies on PPR Low-Cost Flats in Kuala Lumpur. Journal of Design and the Built Environment, 2011.

Goran, Tannerfeldt and Ljung, Per. 2006. More Urban Less Poor: An Introduction to Urban Development and Management. Earthscan. London, UK.

Ha, S.-K. 2004. Housing Poverty and the Role of Urban Governance in Korea. Environment and Urbanization 16: $139-154$

Hamid ZA, Kamar KAM. 2010 Modernising the Malaysian Construction Industry. CIB World Congress 2010: Salford, United Kingdom; 2010.

Hamzah H. 2012 State intervention in housing the urban poor in the developing State of Terengganu in Malaysia: An institutional analysis of low-cost housing regulations and their impacts on low-cost housing provision. Property. vol. PhD. University of Auckland: New Zealand; 2012.

ILO. 2010 Household Income and Expenditure Statistics Department of Statistics, International Labour Organization (ILO); LABORSTA Internet: Geneva, Switzerland; 2010.

iProperty. 2015a Pearl Villas, Petaling Jaya. Downloaded from http://www.iproperty.com.my/propertylisting/288648/section-16-semi-detached-house-forsale

iProperty. 2015b One KL Condominium. Downloaded from http://www.iproperty.com.my/condominiums/condo_gallery.aspx?bid=1759

Ismail E. 2003 Achieving Quality in Housing Construction through Standardization. 2nd Asian Forum Conference. Institute of International Harmonization for Building and Housing Tokyo; 2003.

Ju, Seo Ryeung \& Omar, Saari. 2011 A typology of modern housing in Malaysia .International Journal of Human Ecology. pp. 109-119

Khair N, et al. 2012 Physical Environment for Post Occupancy Evaluation in Public Low-Cost Housing. 3rd International Conference on Business and Economic Research (3rd ICBER 2012). Conference Master Resources: Bandung, Indonesia; 2012. pp. 248 - 261. 
Litman T. 2013 Affordable-Accessible Housing In A Dynamic City. Why and How To Increase Affordable Housing Development In Accessible Locations. Victoria Transport Policy Institute; 2013.

MM2H. 2009. Types of Houses in Malaysia [Online]. Ministry of Tourism Malaysia. Downloaded from: http://www.mymm2h.com/property/type-of-houses.html

Mohit MA, et al. 2010. Assessment of residential satisfaction in newly designed public low-cost housing in Kuala Lumpur, Malaysia. Habitat International 2010; 34; 18-27.

Mulliner E, et al. 2013. An assessment of sustainable housing affordability using a multiple criteria decision making method. Omega 2013; 41; 270-279.

Mustafa Z. 2012 Affordable housing boon. New Straits Time Online Portal The New Straits Times Press (Malaysia) Berhad: Kuala Lumpur, Malaysia 2012.

NAPIC. 2015 Property Stock Report: Residential Property Stock Table Q1 2015. Downloaded from http://napic.jpph.gov.my/portal/web/guest/publication?p_p_id=ViewPublishings_WAR_ViewPublishi ngsportlet\&p_p_lifecycle=0\&p_p_state=normal\&p_p_mode=view\&p_p_col_id=column$1 \& p \_p \_c o l \_c o u n t=1 \&$ ViewPublishings_WAR_ViewPublishingsportlet_action=renderReportPeriod Screen \&publishingld $=433$ \&pageno $=1$ \&language $=$

National Housing Department. 2008 National Housing Policy. National Housing Department (NHD): Kuala Lumpur; 2008.

National Housing Department. 2011 National Housing Policy National Housing Department, Ministry of Housing and Local Government: Kuala Lumpur; 2011.

Omar D. 2008. Communal Living Environment in Low Cost Housing Development in Malaysia. Asian Social Sciene 2008; 4; 98-105.

Pope J, et al.2004. Conceptualising sustainability assessment. Environmental Impact Assessment Review $2004 ; 24 ; 595-616$.

Preston V. 2009 Questionnaire Survey. In: K. Rob, T. Nigel, (Eds), International Encyclopedia of Human Geography. Elsevier: Oxford; 2009. pp. 46-52.

Propwall. 2010 The Nomad Residences, Bangsar. Downloaded from http://www.propwall.my/photos/437058/the-nomad-residences-bangsar-photo-by-david

Rakodi, C. 1992. "Housing Markets in Third World Cities: Research and Policy into the 1990s." World Development 20(1): 39-55.

REHDA. 2008 The Way Forward for the Construction Industry. REHDA Bulletin: Towards Sustainable Development. REHDA, Real Estate and Housing Developers' Association Malaysia: Kuala Lumpur; 2008.

Salleh AG. 2008. Neighbourhood factors in private low-cost housing in Malaysia. Habitat International 2008; 32; 485-493.

Shaari SN. 2003. Dirty, Difficult and Dangerous? Simplify It .... Use IBS! Engineers Journal - Institution of Engineers Malaysia 2003; 1; 8-11.

Smith P. 2010 Life Cycle Cost Model for Measuring Housing Affordability. In: F. P. P. Ling, S. K. Yong, (Eds), 7th International Cost Engineering Council World Congress (ICEC) \& 14th Pacific Association of Quantity Surveyors (PAQS) Congress. Singapore Institute of Surveyors \& Valuers (SISV): Singapore; 2010. pp. 1-11.

Sufian A. 2007 Quality Housing for All: An Overview on Regulatory and Administrative Framework in Malaysia. Annual Meeting of The Law and Society Association. The Law and Society Association: Berlin, Germany; 2007.

Sulaiman H, Yahaya N. 1987. Housing provision and satisfaction of low-income households in Kuala Lumpur. Habitat International 1987; 11; 27-38. 
Wan Abd Aziz WNA. 2007 Low-Cost Housing Policy in Malaysia: The Challenge of Delivery. School of Town and Regional Planning. vol. PhD. University of Dundee: Dundee; 2007.

XE. 2013. Universal Currency Converter XE Corporation; 2013.

Yusof, N.A., et al. 2010. Strategies to implement the "build then sell" housing delivery system in Malaysia. Habitat International, 34, 53-58.

Zebardast E. 2006. Housing Affordability for the Different Zones of Tehran City using Factor and Cluster Analysis. International Conference on Sustainable Housing 2006: Universiti Sains Malaysia, Penang, Malaysia; 2006.

\section{End Notes}

${ }^{1}$ Excluding States and local authorities-provided housing (EPU, 2010), therefore implies the low-cost housing units built are Federal government funded low-cost housing.

ii Anonymity needs to be managed in order to avoid biased answers to the questionnaire (Schofield, 1996). Therefore, the survey only records the unit number of households and not the registered name of the household. It was also made clear to respondents that the results of the survey would only be used for this research project, and was independent of any governmental agency. These measures were deliberate steps taken to increase trust between the researcher and the respondents participating in the survey.

iii Countries included International Labour Organization Household Income and Expenditure Statistics are Albania; Andorra; Argentina; Armenia; Australia; Austria; Azerbaijan; Belarus; Belgium;

Botswana; Bulgaria; Croatia; Cyprus; Czech Republic; Denmark; Estonia; Finland; France;

Germany; Gibraltar; Hong Kong, China; Hungary; Iceland; India; Iran, Islamic Rep. Of; Isle Of

Man; Japan; Kazakhstan; Korea, Republic Of; Latvia; Lithuania; Macau, China; Maldives; Mauritius;

Mexico; Moldova, Republic Of.; Myanmar; Netherlands; Niger; Norway;

Panama; Philippines; Poland; Romania; Serbia And Montenegro; Singapore; Slovakia; Spain; Sri

Lanka; Sweden; Switzerland;

Turkey; Uganda; United Kingdom; United States; West Bank And Gaza Strip ILO 2010 Household Income and Expenditure Statistics Department of Statistics, International Labour Organization (ILO); LABORSTA Internet: Geneva, Switzerland; 2010..

iv This percentage includes "water supply and miscellaneous services relating to the dwelling" Department of Statistics Singapore 2008 Report on the Household Expenditure Survey, 2007/08. Publication Catalogue. Department of Statistics Singapore, Government of Singapore: Singapore; 2008.

$\checkmark$ The Total and Average calculations are based on the highest percentage cited and averaged only for 'Fuel' 'Other Utilities' which includes water utilities.

vi Henceforth, the PPR low-cost housing in this paper refers to this definition.

vii Excluding States and local authorities-provided housing EPU 2010 Tenth Malaysia Plan. Economic Development: Development Plans. Economic Planning Unit; 2010., therefore implies the low-cost housing units built are Federal government funded low-cost housing.

viii RM 543 million is approximately USD 175 million or AUD 171 million, as exchange rate of $12^{\text {th }}$ February 2013 XE 2013 Universal Currency Converter XE Corporation; $2013 .$.

ix Only electricity and water utility expenditure will be included in the survey questionnaire as Malaysia is located in the tropical climate region where heating isn't a priority. 